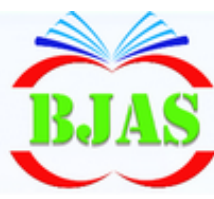

ISSN $1814-5868$
Available online at http://bjas.bajas.edu.iq

https://doi.org/10.37077/25200860.2021.34.1.09

College of Agriculture, University of Basrah
Basrah Journal

of Agricultural

Sciences

E-ISSN: 2520-0860

\title{
Morphology and Molecular Studies of Contracaecum Larvae (Nematoda: Anisakidae) in Some Fish species from Sulaimani Province, Kurdistan Region, Iraq
}

\author{
Younis S. Abdullah ${ }^{1 *}$, Shamall M. A. Abdullah ${ }^{2}$, \& Ridha H. Hussein ${ }^{3}$ \\ ${ }^{1}$ Department of Medical Laboratory, Technical College of Health, Sulaimani Polytechnic \\ University, Iraq \\ ${ }^{2}$ Department of Fish Resource and Aquatic Animal, College of Agricultural Engineering \\ Sciences, University Salahaddin, Erbil, Iraq \\ ${ }^{3}$ Department of Biology, College of Science, University of Sulaimani, Iraq. \\ * Corresponding author: younis.abdullah@spu.edu.iq
}

Received 3 July 2020; Accepted 3 December 2020; Available online 19February 2021

\begin{abstract}
Contracaecum is a genus of nematodes belonging to the family Anisakidae, that parasitise many fishes which act as an intermediate or paratenic hosts, while the piscivorous birds and mammals are definitive hosts. A total of 44 third larval stage of Contracaecum were collected from 13 infected freshwater fishes belonging to five different species in different water bodies in Sulaimani Province, Kurdistan Region, Iraq from January to the end of December 2018. In this investigation, 966 fishes were collected including six species of Nemacheilidae, five species of Cyprinidae, three species of Leuciscidae, two species of Xenocyprididae, one species of each of Bagridae, Heteropneustidae, Mastacembelidae, Mugilidae, Siluridae and Sisoridae. This study revealed that five fish species (Cyprinus carpio, Luciobarbus barbulus, L. esocinus, L. xanthopterus and Mastacembelus mastacembelus) were infected with Contracaecum larvae with the prevalence of $2.05 \%$, $0.92 \%, 1.92 \%, 19.35 \%$ and $1.06 \%$, respectively. The Contracaecum larvae were morphologically studied by compound light microscope and the molecular analyses was done by amplification, sequencing and comparing different gene loci (ITS1, ITS2 and COX2) of isolated third larval stage of Contracaecum. The ITS1, ITS2 and COX2 were amplified by polymerase chain reaction (PCR) and sequenced. The sequences of ITS1, ITS2 and COX2 reveal that all Contracaecum larvae from all infected fishes represented exactly one species (Contracaecum rudolphii B) based on compering and identity percentage in Gene Bank database. Phylogenetic analysis of the genotype (for ITS1) was described. The genetic characterization of the Contracaecum larvae in the present study is available in the GenBank database and they were deposited in GenBank and their accession numbers were demonstrated.
\end{abstract}

Keywords: Contracaecum larva, Nematoda, Freshwater fishes, Sequence analysis.

\section{Introduction}

Contracaecum is the most specious and diverse genus of parasitic nematodes of the family Anisakidae and they are cosmopolitan in their distribution (Szostakowska \& Fagerholm, 2007). The larval stage of Contracaecum usually infect invertebrate 
crustaceans and a wide range of fish species (Anderson, 2000). The adult stage can infect both terrestrial and aquatic animals (Shamsi, 2019). They also have a zoonotic significance (Bezerra et al., 2019; Pekmezci and Yardimci, 2019). Anisakid larvae (L3) may accidentally infect human through eating raw, smoked, or undercooked fish and leading to a sever disease known as anisakidosis (anisakiasis), a zoonotic disease characterized by stomach pains, fever, diarrhea and vomiting, particularly the species belonging to Anisakis, Contracaecum and Pseudoterranova (Oshima, 1987; Arslan et al., 1995; Yagi et al., 1996; Audicana et al., 2002; Shamsi \& Butcher, 2011). This disease has been reported worldwide, and it is endemic in Southeast Asia (Audicana \& Kennedy, 2008; Mattiucci \& Nascetti, 2008).

Species of the genus Contracaecum differ from all other Anisakidae by having two oppositely-directed caecae as part of their digestive system, and their excretory pore is located at the anterior end of the parasite (Køie \& Fagerholm, 1995). Specific identification of Contracaecum larvae in fish hosts to the species level, based on morphological characters is impossible. The scientists in the world investigate the genetic characterization for specific identification of Contracaecum larvae by using different genetic markers such as 28S rDNA, 18S rDNA, ITS1, ITS2, mtDNA COX2 (Garbin et al. 2013; Mattiucci et al. 2015; Younis et al., 2017; Malviya et al., 2018; Zuo et al. 2018). The first record of Contracaecum larva in fish from Iraq was by Herzog (1969). After that record, these larvae were recorded in many freshwater fishes in different Iraqi water bodies by many researchers as shown in table
(1). Furthermore, there are few publications on the specific identification of Contracaecum larva in fishes from the world (Szostakowska \& Fagerholm, 2007; Shamsi \& Aghazadeh-Meshgi, 2011; Shamsi et al., 2017; Molnár et al., 2019; Pekmezci \& Yardimci, 2019). The present investigation identifies the third larval stage of Contracaecum by using molecular genetic approach. The previous studies reveal that the molecular approach is useful for accurate identification of Contracaecum larva to species level (Shamsi et al., 2011).

\section{Materials \& Methods:}

\section{Description of Study Area:}

Sulaimani Province is situated in the northeast of Iraq, between the latitudes of $35^{\circ} 05^{\prime}$ and $36^{0} 30^{\prime}$ and between longitudes of ' $44^{0} 25^{\prime}$ and $46^{0} 20^{\prime}$. It is located close to the Iraqi-Iranian border. This province is rich with many water bodies in addition to presence of two main rivers: Lesser Zab River and Sirwan River which pass through this Province (Fig. 1).

\section{Collection and Preservation of the specimens}

From January to the end of December 2018, a total of 966 fish specimens were collected and searched for infection with Contracaecum larvae.

These fishes belong to five species of Cyprinidae, three species of Leuciscidae, two species of Xenocyprididae, six species of Nemacheilidae and one species each of Bagridae, Mastacembelidae, Muglidae, Siluridae and Sisoridae (Table 2). 
Abdullah et al. / Basrah J. Agric. Sci., 34(1): 93-110, 2020

Table (1): Some previously record of Contracaecum larva in different fish species in Iraq.

\begin{tabular}{|c|c|c|}
\hline Hosts & Locality & Sources \\
\hline $\begin{array}{l}\text { A. grypus, C. luteus, H. fosilis, L. vorax, } \\
\text { L. esocinus, L. xanthopterus, M. } \\
\text { sharpeyi, M. pelusius, P. abu and S. } \\
\text { triostegus }\end{array}$ & Different inland water & Herzog, 1969 \\
\hline S. triostegus and P. abu & Local fish market & Shamsuddin et al., 1971 \\
\hline S. triostegus & Tigris River, Baghdad & Khalifa et al., 1978 \\
\hline C. luteus, L. vorax and L. abu & $\begin{array}{c}\text { Shatt Al-Arab River, } \\
\text { Basrah }\end{array}$ & Mhaisen et al., 1986 \\
\hline $\begin{array}{l}\text { A. centisquama, C. macrostomum, } H \text {. } \\
\text { fossilis and L. cephalus }\end{array}$ & Tigris River, Baghdad & Ali et al., 1987 \\
\hline P. $a b u$ & Babylon fish farm & Ali et al., 1989 \\
\hline P. $a b u$ and $H$. fossilis & Tigris River, Baghdad & Balasem et al., 1993 \\
\hline $\begin{array}{l}\text { A. vorax, A. grypus, C. luteus, H. fosilis, } \\
\text { L. clussumieri, L. xanthopterus, M. } \\
\text { sharpeyi, M. pelusius, P. abu and S. } \\
\text { triostegus }\end{array}$ & Basrah & Mhaisen et al., 1993 \\
\hline P. $a b u$ & Al-Habbaniyah Lake & Mhaisen et al., 1999 \\
\hline C. carpio & $\begin{array}{l}\text { Man-made lake, } \\
\text { Baghdad }\end{array}$ & Al-Nasiri et al., 2002 \\
\hline P. $a b u$ & Al-Diwanyah & Al-Jadoa, 2008 \\
\hline $\begin{array}{l}\text { A. dispar, A. grypus, G. affinis and } P \text {. } \\
\text { abu }\end{array}$ & Al-Najaf & $\begin{array}{l}\text { Al-Awadi \& Mhaisen, } \\
2010\end{array}$ \\
\hline C. carpio, L. xanthopterus and L. vorax & Euphrates, Al-Anbar & Al-Alusi, 2011 \\
\hline C. carpio & Basrah & Eassa et al., 2014 \\
\hline T. zilli & Al-Diwanyah, Thi-Qar & Mohammad, 2016 \\
\hline S. triostegus & Tigris River, Baghdad & $\begin{array}{l}\text { Al-Moussawi et al., } \\
2018\end{array}$ \\
\hline
\end{tabular}

The fishes were caught by gillnetting and pulsed DC electro-shock device SAMUS 1000 (made in Poland). The collected fishes were identified based on their morphometric and meristic characters (Coad, 2010; Kamangar et al., 2014; Freyhof et al., 2016; Freyhof \& Abdullah, 2017; Freyhof \& Geiger, 2017). The fishes were transported to parasitological laboratory for parasitological examinations. The fishes were dissected; the body cavity, heart, liver, spleen, kidneys, swim bladder, gonads and muscles were all examined for Contracaecum cysts. The gastrointestinal tracts were dissected out from the rectum to the esophagus, opened and examined carefully (Amlacher, 1970). The cysts were removed and washed with normal saline $(0.9 \%)$ in disposable plastic Petri dishes. Under dissecting microscope, the cysts were teared down with the aid of a fine needle to release the Contracaecum larvae, washed with saline solution and then preserved in 
ethanol (70\%). Prevalence and intensity of infection were calculated for each fish species based on the terminology of Bush et al. (1997).

\section{Morphological study}

The Contracaecum larvae were collected and washed with saline solution $(0.9 \%)$, fixed in hot $\left(60{ }^{\circ} \mathrm{C}\right)$ formaldehyde solution $(4 \%)$ in order to relax their bodies and then preserved in ethanol (70\%). A small piece of the larval mid-body was excised for molecular study and preserved directly in absolute ethanol. The Contracaecum larvae were cleared in glycerin (Moravec, 2009; Moravec \& Yooyen, 2011).

The parasitic measurements were made with an ocular micrometer (Olympus) and given in millimeters. The photos were taken with Digital camera model DSC-W570, 16.1 mega pixels (Sony). The parasitic larvae were identified at a genus level according to their morphology and key features and descriptions of Anderson (2000).

Table (2): List of fishes collected from different water bodies in Sulaimani Province with their numbers.

\begin{tabular}{|c|c|}
\hline Family and Scientific Names & Number \\
\hline Family: Cyprinidae Rafinesque, 1815 & \\
\hline Cyprinus carpio Linnaeus, 1758* & 195 \\
\hline Garra rufa (Heckel, 1843) & 57 \\
\hline Luciobarbus barbulus (Heckel, 1849) & 108 \\
\hline Luciobarbus esocinus Heckel, 1843 & 52 \\
\hline Luciobarbus xanthopterus Heckel, 1843 & 31 \\
\hline Family: Leuciscidae Bonaparte 1835 & \\
\hline Leuciscus vorax (Heckel, 1843) & 1 \\
\hline Squalius cephalus (Linnaeus, 1758) & 37 \\
\hline Squalius lepidus Heckel, 1843 & 62 \\
\hline $\begin{array}{l}\text { Family: Xenocyprididae Günther } 1868 \\
\text { Hemiculter leucisculus (Basilewsky, 1855)* }\end{array}$ & 121 \\
\hline Hypophthalmichthys molitrix (Valenciennes, 1844)* & 2 \\
\hline $\begin{array}{l}\text { Family: Bagridae Bleeker, } 1858 \\
\text { Mystus pelusius (Solander, 1794) }\end{array}$ & 8 \\
\hline $\begin{array}{l}\text { Family: Heteropneustidae Hora, 1936a } \\
\text { Heteropneustes fossilis (Bloch, 1794)* }\end{array}$ & 8 \\
\hline $\begin{array}{l}\text { Family: Mastacembelidae Swainson, } 1839 \\
\text { Mastacembelus mastacembelus (Banks \& Solander, 1794) }\end{array}$ & 94 \\
\hline $\begin{array}{l}\text { Family: Mugilidae Cuvier, } 1829 \\
\text { Planiliza abu (Heckel, 1843) }\end{array}$ & 76 \\
\hline $\begin{array}{l}\text { Family: Nemacheilidae Regan, } 1911 \\
\text { Eidinemacheilus proudlovei Freyhof, Abdullah, Ararat, Hamad \& Geiger, } 2016\end{array}$ & 40 \\
\hline Oxynoemacheilus gyndes Freyhof \& Abdullah, 2017 & 14 \\
\hline Oxynoemacheilus hanae Freyhof \& Abdullah, 2017 & 5 \\
\hline Oxynoemacheilus kurdistanicus Kamangar, Prokofiev, Ghaderi \& Nalbant, & 12 \\
\hline
\end{tabular}


Abdullah et al. / Basrah J. Agric. Sci., 34(1): 93-110, 2020

\begin{tabular}{|l|c|}
\hline 2014 & \\
\hline Oxynoemacheilus zarzianus Freyhof \& Geiger, 2017 & 2 \\
\hline Turcinoemacheilus kosswigi Bănărescu \& Nalbant, 1964 & 2 \\
\hline $\begin{array}{l}\text { Family: Siluridae Cuvier, 1816 } \\
\text { Silurus triostegus Heckel, 1843 }\end{array}$ & 20 \\
\hline $\begin{array}{l}\text { Family: Sisoridae Bleeker, 1858 } \\
\text { Glyptothorax kurdistanicus (Berg, 1931) }\end{array}$ & 19 \\
\hline Total & 966 \\
\hline
\end{tabular}

*: Exotic fish;

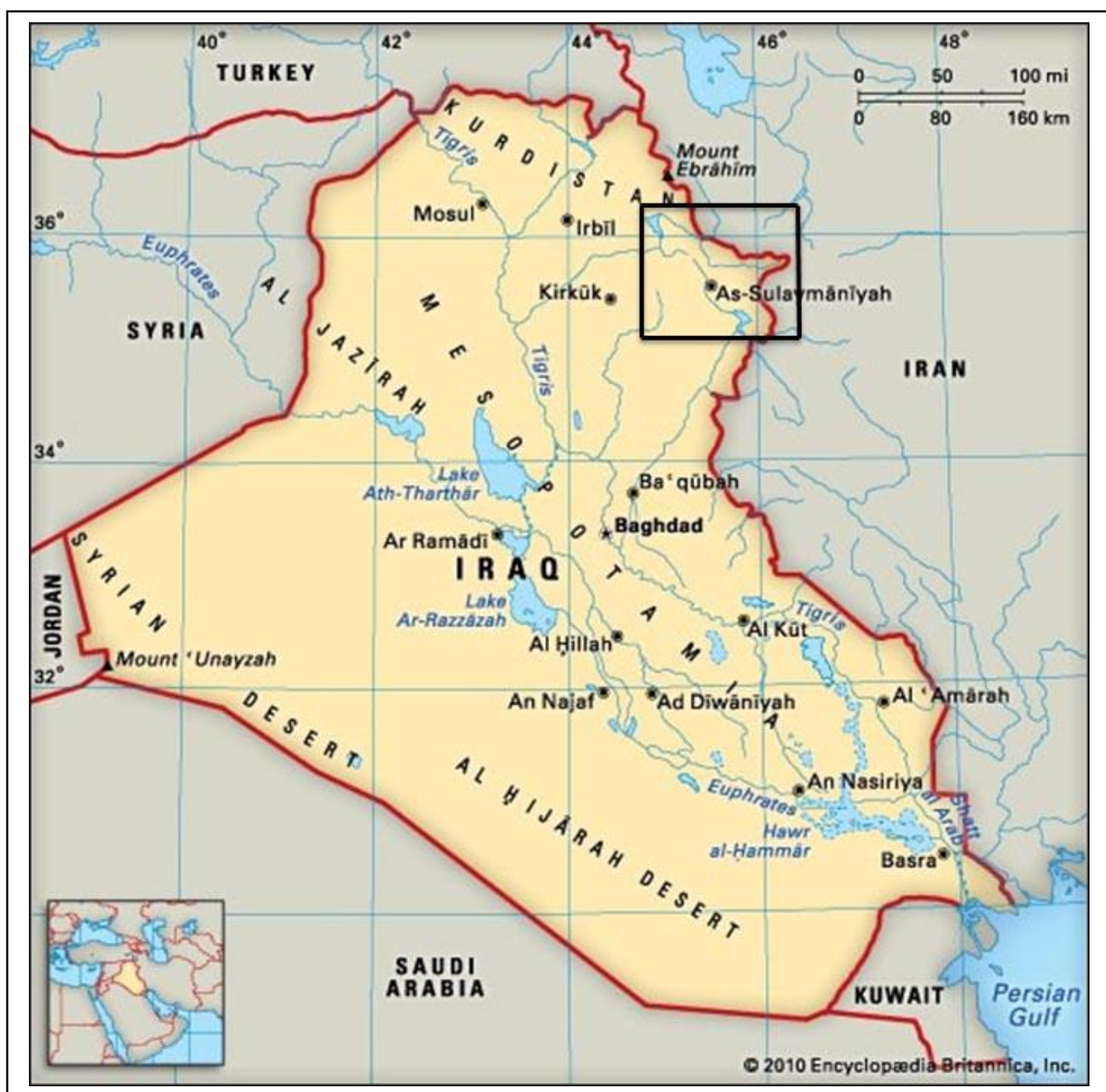

Fig. (1): Map of Iraq showing the study area.

\section{Molecular study}

\section{A- DNA extraction}

Before the molecular studies, each Contracaecum larva was identified based on morphology under optical microscope.
Genomic DNA was isolated from mid piece of individual larvae by using QIAamp ${ }^{\circledR}$ DNA Mini Kit with a bit modification. In brief, the mid piece of individual Contracaecum larval parasites were cut into small pieces, digested with proteinase $\mathrm{K}$ in ATL buffer for 3 hours at $56{ }^{\circ} \mathrm{C}$ and then the obtained DNA were 
eluted into $50 \mu \mathrm{l}$ of $\mathrm{AE}$ buffer $\left(\mathrm{QIAamp}{ }^{\circledR}\right.$ DNA Mini Kit).

\section{B- DNA amplification}

Polymerase chain reaction (PCR) was used to amplify three gene loci (ITS1, ITS2 and COX2). The specific sets of primer SS1F/NC13R, SS2F/NC2R (Shamsi et al., 2008) and 210F/211R (Nadler \& Hudspeth, 2000) were used to amplify two nuclear ribosomal markers (ITS1 and ITS2) and mitochondrial cytochrome oxidase II (COX2), respectively.

PCR was performed (in a volume of $30 \mu \mathrm{l}$ ) in $25 \mathrm{mM}$ Tris- $\mathrm{HCl}, \mathrm{pH} \mathrm{9.0,} \mathrm{at} 25^{\circ} \mathrm{C}, 2 \mathrm{mM}$ $\mathrm{MgCl}_{2}, 50 \mathrm{mM} \mathrm{KCl}, 0.1 \mathrm{mg} / \mathrm{ml}$ gelatin, 200 $\mu \mathrm{M}$ de dATP, dGTP, dTTP, $100 \mu \mathrm{M}$ [a32-P] de CTP $(0.05 \mu \mathrm{Ci} / \mathrm{nmol})$ and $12.5 \mu \mathrm{g}$ salmon sperm DNA (activated) and 10 pmol of each primer and 1.5 U Taq polymerase (Canvax Biotech, S.L.). The PCR reactions took place a thermocycler (Applied Biosystems 2720, USA) using this cycling instructions: initial denaturation at $94^{\circ} \mathrm{C}$ for $5 \mathrm{~min}$, denaturation at $94^{\circ} \mathrm{C}, 30 \mathrm{sec}$ for 35 cycles, annealing at $55^{\circ} \mathrm{C}, 30 \mathrm{sec}$, extension at $72^{\circ} \mathrm{C}, 30 \mathrm{sec}$ and the final extension at $72^{\circ} \mathrm{C}$ for $7 \mathrm{~min}, 4^{\circ} \mathrm{C} \infty$. $2 \mu \mathrm{l}$ of genomic DNA (20-40 ng). Deionized distilled water was added to each PCR reaction. Specimen with fish genomic DNA that extracted from muscle was included in the PCR as negative control from these specimens, no amplicons were produced. Five $\mu 1$ of each PCR product was examined on a $1.5 \% \mathrm{w} / \mathrm{v}$ agarose gel, stained with DNA stain (Good View $^{\mathrm{TM}}$ SBS Genetech Beijing, China), 1000 bp DNA ladder (Vivantis, Malaysia) was used and photographed by using a gel documentation system. The expected size of the PCR amplicon was $\sim 530 \mathrm{bp}$ for ITS1, $430 \mathrm{bp}$ for ITS2 and $\sim 629$ bp for COX2. After that, the amplicon were purified using EasyPure ${ }^{\circledR}$ Quick Gel
Extraction Kit (TRANSGEN BIOTECH), according to the manufacturer's protocols. The purified products were sent to the Macrogen Company (South Korea) for nucleotide sequence analyses by a dideoxy termination method using Genetic analyzer 3500, an applied Biosystems (USA) DNA Sequencer in the two directions (forward and reverse) with the same primer that used in the PCR.

\section{C- Computer based sequence analysis}

The resulted ITS1, ITS2 and COX2 sequences (forwards) were compared with their complements (reverses) and then adjusted using online software tool (bioinformatics.org $\backslash$ sms $\backslash r e v \_c o m p . h t m l$ ) to obtain reverse complement. Then, the resulted sequences were aligned to each other using multiple sequence alignment program by using the online software program CLUSTALW (genome.jp/tools-bin/clustalw) to get the most homologous sequences (one sequence). Subsequently, the obtained sequences were put into the NCBI Blast program for homology search (http://www.ncbi.nlm.nih.gov/). In addition, the multiple sequence alignment were done for each obtained sequences from each gene (ITS1, ITS2 and COX2) in all Contracaecum larvae collected from five different fish host species by using the online software program CLUSTALW (genome.jp/tools-bin/clustalw), in order to obtain nucleotide variation among Contracaecum larvae in different fish host species.

The sequence data of ITS1 fragments obtained from Contracaecum larvae collected from five different fish host species in the present study were installed into the MEGA X version 10.7.1 software program (Kumar et al., 2018). To unify the length of the sequences, the common 447 bp length of 
ITS1 segments were selected and used for phylogenetic analysis to determine the most appropriate sequence evolution model for the given data, treating gaps and missing data with the partial deletion option. The sequences were aligned using CLUSTALW alignment for constructing the trees of evolutionary development. The trees of all isolated species were constructed based on the Maximum Likelihood (ML) method and Tamura-Nei model (Tamura \& Nei, 1993).

\section{Results \& Discussion}

\section{Prevalence of infection}

In the present investigation, 966 fish specimens were examined for the presence of Contracaecum larvae. The larvae $(n=44)$ were found in the mesentery, liver and on the intestinal wall of 13 fishes belonging to five different species. The total prevalence of infection was $1.34 \%$ (13\966) as shown in Table (3).

The highest prevalence of Contracaecum larva was recorded in $L$. xanthopterus (19.35\%), while the lowest was occurred in $L$. barbulus $(0.92 \%)$. These results agree with Abdullah \& Rasheed (2004) who recorded Contracaecum larva in $L$. xanthopterus (reported as Barbus xanthopterus) and $L$. barbulus (reported as Barbus barbulus) with prevalences of $44.4 \%$ and $7.1 \%$, respectively among 11 fish species in Dukan Lake. These variations in the prevalence may be due to water level, temperature, intensity of both intermediated host and piscivorous bird (final host), and types of food and feeding habits of the fishes (Younis et al., 2017).

\section{Morphological identification}

Morphological study and measurements of the larvae were done by optical microscope and showed that the larvae of the present study were the third larval stage (L3) of
Contracaecum as described by Moravec (2009). As well as there were no any significant morphological differences among the larvae which were recorded in different fish species.

The collected Contracaecum larvae were light brownish-yellow. They have cylindrical body, anterior end was provided with a distinct boring tooth, tail was short with rounded tip. Their bodies were covered with fine, dense transverse striation of cuticle. The encapsulated larvae were with slender body, posterior ventricular appendix and anterior intestinal caecum. Excretory pore is located at the level of base of lips, cuticular striations were observed throughout the all length of the body. Esophagus is composed of a long muscular part and a short glandular ventriculus. Small numerous brownish granules filled the intestine. Reproductive system (gonads and other accessory organ) were not developed (Fig. 2).

Total length of the larva is $3.3-5.20 \mathrm{~mm}$, width 0.17-0.75 mm. Esophagus length 0.07$0.75 \mathrm{~mm}$. Intestinal caecum length 0.04-0.40 $\mathrm{mm}$. esophageal caecum length 0.07-0.52 mm (Table 4). This parasite, in the third larval stage (L3), lacks the gonads and other parts of the reproduction system. It is difficult to determine the exact classification status at the species level based on morphological study only. The present Contracaecum larvae are in a close resemblance to the third larval stage of Contracaecum that studied by Moravec (2009) in C. carpio from Czech Republic in both measurements and characters. There were no significant morphological variations among the Contracaecum larvae which they were recorded in the present study in the different fish species. Photomicrographs of the third larval stage (L3) of Contracaecum in L. xanthopterus were demonstrated in fig. (2). 


\section{Polymer chain reaction $(\mathrm{PCR})$}

The PCR were done by amplifying ITS1, ITS2 and COX2 regions from individual larvae. The agarose gels analyses revealed the same size for each ITS1, ITS2 and COX2 regions. The amplicons were $\sim 530 \mathrm{bp}, \sim 430$ bp and $\sim 630 \mathrm{bp}$ for the ITS1, ITS2, and COX2 (not shown), respectively, which confirm that all the obtained sequences were from the same genus.

\section{Sequence and phylogenic analysis}

The alignment of resulted sequences demonstrated that there was no significant variation of each ITS1, ITS2 and COX2 regions, which indicates the presence of only one type of larvae.

Based on percentage identities of nucleotide sequences from GenBank, the online BLAST tool showed the ITS1 sequences obtained from larvae from $C$. carpio, L. barbulus, $L$. esocinus, L. xanthopterus and $M$. mastacembelus matched 100\%, 100\%, $99.55 \%, 100 \%$ and $100 \%$, respectively to the previously reported reference gene sequences for the ITS-1 in Contracaecum rudolphii type-B (Zhang et al., 2009) isolated from the intestinal canal of great cormorant Phalacrocorax carbo sinensis from the Guangzhou Zoo in Guangdong in China, which was previously examined and deposited in GenBank under accession number FJ467618 (Zhang et al., 2009).

The ITS2 sequences obtained from larvae infecting C. carpio, L. barbulus, L. esocinus, L. xanthopterus and M. mastacembelus matched $100 \%$ to the previously reported reference gene sequences for the ITS-2 in Contracaecum rudolphii type-B (Zhang et al., 2009) isolated from the intestine of great cormorant Phalacrocorax carbo sinensis from the Guangzhou Zoo in Guangdong in China, which was previously examined and deposited in GenBank under accession number FJ467620 (Zhang et al., 2009).

Table (3): Prevalence of Contracaecum larva and mean of intensity among fish species.

\begin{tabular}{|c|c|c|c|c|c|}
\hline \multirow[t]{2}{*}{ Hosts } & \multicolumn{2}{|c|}{ Fishes } & \multirow{2}{*}{$\begin{array}{c}\text { Prevalence } \\
\%\end{array}$} & \multirow{2}{*}{$\begin{array}{c}\text { Mean } \\
\text { intensity }\end{array}$} & \multirow[t]{2}{*}{ Site of infection } \\
\hline & Examined & Infected & & & \\
\hline C. carpio & 195 & 4 & $2.05 \%$ & 2.75 & Intestinal wall \\
\hline L. barbulus & 108 & 1 & 0.92 & 6 & Intestine wall \\
\hline L. esocinus & 52 & 1 & 1.92 & 6 & Intestine wall \\
\hline L. xanthopterus & 31 & 6 & 19.35 & 2.66 & Intestine wall \\
\hline M. mastacembelus & 94 & 1 & 1.06 & 5 & Mesentery, liver \\
\hline
\end{tabular}


Abdullah et al. / Basrah J. Agric. Sci., 34(1): 93-110, 2020
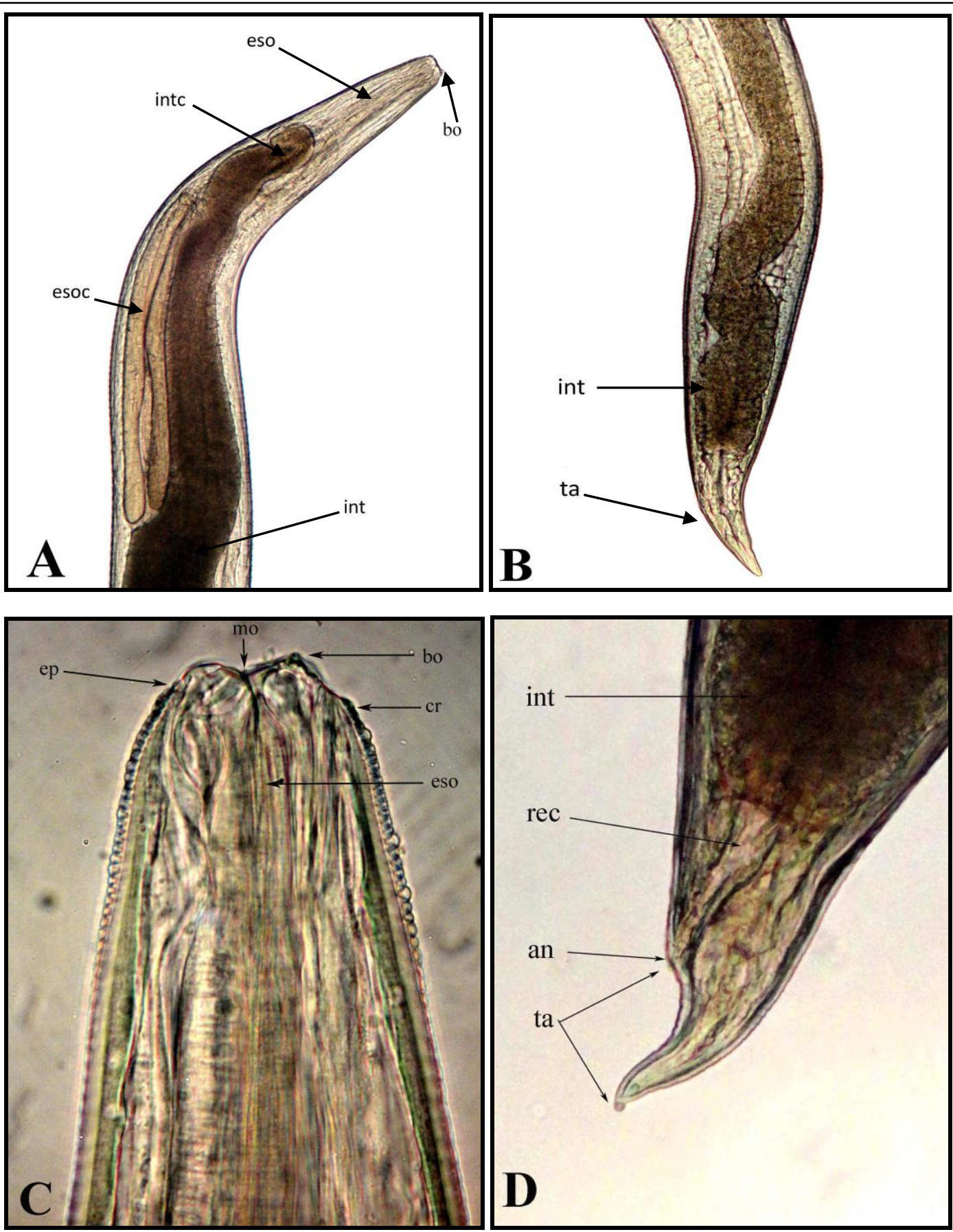

Fig. (2): Photomicrographs of Contracaecum larva in L. xanthopterus

A- Anterior part of the larva (100X).

B- Posterior part of the larva (100X).

C- Mouth region of the larva (400X).

D- Tail region of the larva (400X).

$\mathbf{a n}=$ anus; $\mathbf{b o}=$ boring tooth $\mathbf{c r}=$ cuticle ridges; $\mathbf{e p =}$ excretory pore; $\mathbf{e s o}=$ esophagus; $\mathbf{e s o c}=$ esophageal caecum; int $=$ intestine; intc $=$ intestinal caecum; $\mathbf{m o}=$ mouth opening; $\mathbf{r e c}=$ rectum; $\mathbf{t a}=$ tail . 
Abdullah et al. / Basrah J. Agric. Sci., 34(1): 93-110, 2020

Table (4): Comparison of measurements of systematically important features in Contracaecum larvae in different fish species in the present study (in millimeter).

\begin{tabular}{|l|c|c|c|c|c|}
\hline Mest & C. carpio & L. barbulus & L. esocinus & L. xanthopterus & M. mastacembelus \\
& & & & & \\
Total length & $3.20-3.80$ & $3.10-3.90$ & $4.30-5.70$ & $3.00-3.70$ & $4.80-5.60$ \\
& $(3.50)$ & $(3.50)$ & $(5.00)$ & $(3.35)$ & $(5.20)$ \\
\hline Maximum width & $0.22-0.28$ & $0.17-0.23$ & $0.20-0.30$ & $0.15-0.19$ & $0.72-0.78$ \\
& $(0.25)$ & $(0.20)$ & $(0.25)$ & $(0.17)$ & $(0.75)$ \\
\hline Tail length & $0.08-0.09$ & $0.078-0.082$ & $0.078-0.082$ & $0.08-0.10$ & $0.035-0.045$ \\
& $(0.085)$ & $(0.08)$ & $(0.08)$ & $(0.09)$ & $(0.04)$ \\
\hline Rectum length & $0.06-0.08$ & $0.064-0.086$ & $0.06-0.08$ & $0.06-0.08$ & $0.029-0.031$ \\
& $(0.07)$ & $(0.07)$ & $(0.07)$ & $(0.07)$ & $(0.03)$ \\
\hline Boring tooth length & $0.004-0.006$ & $0.004-0.006$ & $0.004-0.006$ & $0.004-0.006$ & $0.0074-0.0076$ \\
& $(0.005)$ & $(0.005)$ & 0.005 & $(0.005)$ & $(0.0075)$ \\
\hline Esophagus length & $0.60-0.80$ & $0.66-0.70$ & $0.72-0.78$ & $0.65-0.71$ & $0.65-0.75$ \\
& $(0.70)$ & $(0.68)$ & $(0.75)$ & $(0.68)$ & $(0.70)$ \\
\hline Esophageal caeca & $0.68-0.72$ & $0.43-0.57$ & $0.48-0.52$ & $0.44-0.56$ & $0.47-0.53$ \\
length & $(0.70)$ & $(0.50)$ & $(0.52)$ & $(0.50)$ & $(0.50)$ \\
\hline Intestinal caeca length & $0.46-0.50$ & $0.28-0.32$ & $0.38-0.42$ & $0.28-0.32$ & $0.35-0.39$ \\
& $(0.48)$ & $(0.30)$ & $(0.40)$ & $(0.30)$ & $(0.37)$ \\
\hline \% tail to & $2.50 \%-2.36 \%$ & $2.51 \%-2.10 \%$ & $1.81 \%-1.43 \%$ & $2.66 \%-2.70 \%$ & $0.72 \%-0.80 \%$ \\
body length & $(2.42 \%)$ & $(2.28 \%)$ & $(1.60 \%)$ & $(2.68 \%)$ & $(0.76 \%)$ \\
\hline Ratio of intestinal & $1: 0.14$ & $1: 1.66$ & $1: 1.30$ & $1: 1.66$ & $1: 1.35$ \\
caecum to esophageal & & & & & \\
caecum & & & & & \\
\hline
\end{tabular}

Furthermore, they matched $100 \%$ to the previously reported reference gene sequences for the ITS2 in Contracaecum rudolphii typeB (Li et al., 2005) from the same host from the Venice lagoon in northeastern Italy and from Monaci Lake in central Italy, which was previously examined and deposited in GenBank under accession number AJ634786 (Li et al., 2005).

The COX2 sequences obtained from larvae infecting C. carpio matched $99.79 \%$ to the previously reported reference gene sequences for the COX2 in Contracaecum rudolphii type-B isolated from the intestine of great cormorant Phalacrocorax carbo sinensis from Italy, which was previously examined and deposed in GenBank under accession number EF558894 (Mattiucci et al., 2008). COX2 sequences obtained from larvae infecting $L$. barbulus, L. esocinus, L. xanthopterus and $M$. mastacembelus matched 100\%, 99.37\%, $100 \%$ and $99.58 \%$, respectively to the previously reported reference gene sequences for the COX2 in Contracaecum rudolphii type-B (Mattiucci et al., 2008) isolated from the great cormorant Phalacrocorax carbo sinensis from Italy, which previously was examined and deposited in GenBank under accession number EF513509 (Mattiucci et al., 2008).

The genetic characterization of the Contracaecum parasite in the present investigation is available in the GenBank. In addition, the ITS1, ITS2 and COX2 sequences obtained were deposited in GenBank and their accession numbers were demonstrated in Table (5). The obtained sequences (ITS1, ITS2 and COX2) from individual Contracaecum larva in the different hosts were aligned with the aid of 
the online computer program CLASTALAW (https://www.genome.jp/tools-bin/clustalw) then adjusted manually. The results as follow:

ITS1 appeared nucleotide variations in alignment position 161, and the ITS2 showed no nucleotide variations in alignment while, COX2 showed nucleotide variations in alignment positions $27,33,36,54,57,78$, $117,168,177,282,318,336,474$ and 480 (not shown).

For the evolutionary study, the obtained sequence data of ITS1 from collected Contracaecum larvae in the present study were subjected to phylogenetic analysis. The sequence data aligned with the data sequence of ITS1 form other 12 different species (16 different genotypes) of Contracaecum detected in GenBank (Accession numbers: AJ634782 Contracaecum rudolphii A, AJ634783 C. rudolphii B, FM210251 $C$. rudolphii D, FM210257 C. rudolphii E, JF424597 C. rudolphii F, AJ291468 C. ogmorhini, AJ007461 C. eudyptulae, HQ389546 C. chubutensis, MK424804 C. variegatum, FM177523 C. microcephalum, AJ634784 C. septentrionale, JF424598 C. bioccai, AY603529 C. radiatum, AB277825 C. osculatum, AM940056 C. multipapillatum, AM940062 C. pyripapillatum) and Ascaris sum (AB110023) as outgroup. So, in this analysis, 22 nucleotide sequences were involved. Evolutionary analyses were conducted in MEGA X (Kumar et al., 2018). The phylogenetic analysis was done by using the maximum likelihood (ML) method (Fig. 3 ). The evolutionary history was inferred by using the Maximum Likelihood (-6699.73) is shown. Intial tree for the heuristic search were obtained automatically by applying NeighborJoin and BioNJ algorithms to a matrix of pairwise distance estimated using the Maximum Composite Likelihood (MCL) approach and then selecting the topology with superior log likelihood value. The tree is drawn to scale, with branch lengths measured in the number of substitutions per site (next to the branches).

Table (5): Accession numbers of different Contracaecum spp. provided by NCBI and used for building the phylogenetic tree.

\begin{tabular}{|l|c|c|c|}
\hline \multicolumn{1}{|c|}{$\begin{array}{c}\text { Host of } \\
\text { Contracaecum rudolphii }\end{array}$} & DNA region & $\begin{array}{c}\text { Accession } \\
\text { numbers }\end{array}$ & References \\
\hline Arabesque greenling & ITS & AB277825 & Umehara et al. (2008) \\
\hline Arctocephalus pusillus doriferus & ITS1 & AJ291468 & Zhu et al. (2001) \\
\hline Bird & ITS1 & MK424804 & Hbaiel \& Mohammad (unpublished) \\
\hline Leptonechotes weddlli & ITS & AY603529 & Kijewska et al. (2008) \\
\hline Pelecanus conspicillatus & ITS1 & AM940056 & Shamsi et al. $(2008)$ \\
\cline { 2 - 4 } & ITS1 & AM940062 & Shamsi et al. $(2008)$ \\
\hline \multirow{2}{*}{ Pelecanus occidentalis } & ITS & JF424597 & D'Amelio et al. (2012) \\
\cline { 2 - 4 } & ITS & JF424598 & D'Amelio et al. $(2012)$ \\
\hline Phalacrocorax brasilianus & ITS1 & HQ389546 & Garbin et al. $(2011)$ \\
\hline \multirow{3}{*}{ Phalacrocorax carbo sinensis } & ITS1 & AJ634782 & Li et al. (2005) \\
\cline { 2 - 4 } & ITS1 & AJ634783 & Li et al. $(2005)$ \\
\cline { 2 - 4 } Phalacrocorax melanoleucos & ITS1 & AJ634784 & Li et al. (2005) \\
\hline Phalacrocorax varius & ITS1 & FM177523 & Shamsi et al. (2009a) \\
\hline Unknown & ITS1 & FM210251 & Shamsi et al. (2009b) \\
\cline { 2 - 4 } & ITS1 & FM210257 & Shamsi et al. $(2009 \mathrm{~b})$ \\
\hline & ITS1 & AJ007461 & Zhu et al. (unpublished) \\
\hline
\end{tabular}


Abdullah et al. / Basrah J. Agric. Sci., 34(1): 93-110, 2020

\begin{tabular}{|l|l|l|l|}
\hline \multirow{2}{*}{ C. carpio } & ITS2 & MN563731 & Present study \\
\cline { 2 - 4 } & Cox2 & MN590002 & Present study \\
\hline \multirow{3}{*}{ L. barbulus } & ITS1 & MN557382 & Present study \\
\cline { 2 - 4 } & ITS2 & MN563732 & Present study \\
\cline { 2 - 4 } & Cox2 & MN590003 & Present study \\
\hline \multirow{3}{*}{ L. esocinus } & ITS1 & MN557383 & Present study \\
\cline { 2 - 4 } & ITS2 & MN563733 & Present study \\
\cline { 2 - 4 } & Cox2 & MN590004 & Present study \\
\hline \multirow{3}{*}{ M. mastacembelus } & ITS1 & MN557384 & Present study \\
\cline { 2 - 4 } & ITS2 & MN563734 & Present study \\
\cline { 2 - 4 } & Cox2 & MN590005 & Present study \\
\cline { 2 - 4 } & ITS1 & MN557385 & Present study \\
\cline { 2 - 4 } & ITS2 & MN563735 & Present study \\
\cline { 2 - 4 } & Cox2 & MN590006 & Present study \\
\hline
\end{tabular}

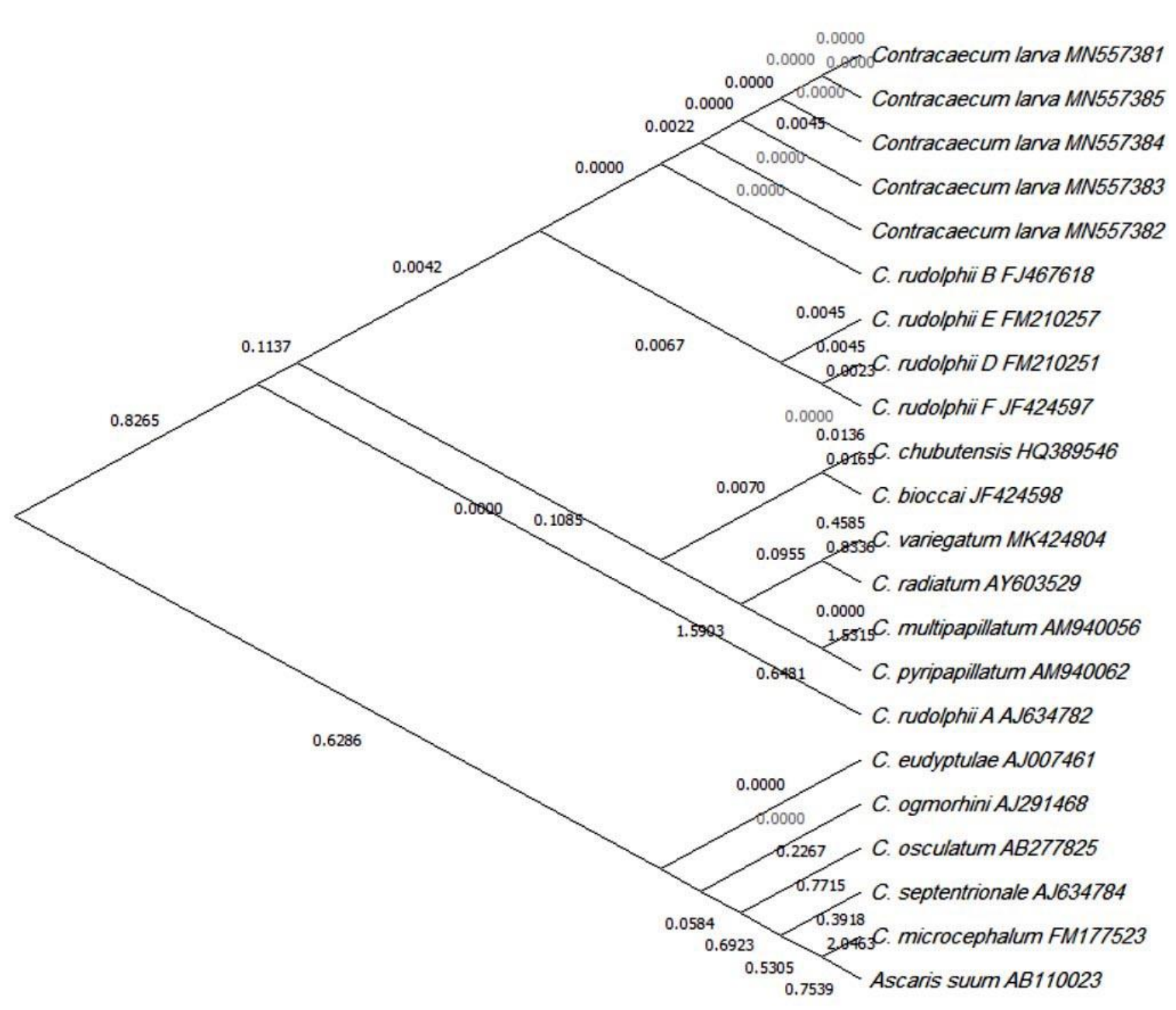

Fig. (3): Phylogenetic relationships between Contracaecum larvae from the present study and other Contracaecum species as inferred by maximum likelihood obtained from ITS1. Ascaris suum was used as outgroup. 
The Contracaecum larvae (MN557381, MN557382, MN557383, MN557384 and MN557385) collected from $C$. carpio, $L$. barbulus, L. esocinus, L. xanthopterus and $M$. mastacembelus in Sulaimani Province, Iraq, and adult C. rudolphii B (FJ467618) from great cormorant Phalacrocorax carbo sinensis in Cuangdong, China were closely related to each other and clustered in the same clade with no (0.0000) sequence divergence, and they were very well supported in the ML tree (Fig. 3) inferred from the ITS1 sequence analysis. Moreover, the phylogenetic tree of the ITS1 sequences using ML analyses indicated that Contracaecum larvae in the present study were distinct species by high bootstrap values (Fig. 3).

The first record of Contracaecum larva in freshwater fishes of Iraq was done by Herzog (1969) from ten fish species from different water bodies of Iraq. In Kurdistan Region, this larva was recorded for the first time by Abdullah \& Rasheed (2004) from Dukan Lake in Sulaimani Province in Arabibarbus grypus (reported as Barbus grypus), Carasobarbus luteus (reported as B. luteus), Chondrostoma regium (misspelled as Chondrostoma regius), Cyprinion macrostomum (misspelled as Cyprinion macrostomus), Cyprinus carpio, Luciobarbus barbulus (reported as Barbus barbulus), L. esocinus (reported as B. esocinus), L. kersin (reported as B. kersin), L. subquincunciatus (reported as B. subquincunciqtus), $L$. xanthopterus (reported as B. xanthopterus), and Squalius lepidus (reported as Leuciscus lepidus). According to Mhaisen \& Abdullah (2017) a total of 21 fish host species are known for Contracaecum larva in Kurdistan Region of Iraq. Furthermore, there are 41 fish host species are known for Contracaecum larvae in Iraq (Mhaisen, 2020).

In the present study, the molecular approach is used toward characterization of larval anisakid nematodes (Contracaecum) in some different fish species in Iraq. On the view of molecular characters, all larvae which were collected from (C. carpio, L. barbulus, L. esocinus, $L$. xanthopterus and $M$. mastacembelust in the present investigation are belonging to Contracaecum rudolphii type-B. It was cleared that the Contracaecum larva can infect more different fish species in Iraq. This larva has low host specificity and this may lead to infect a variety of piscivorous birds and mammals in the region.

Contracaecosis is a disease caused by the accidental ingestion of larval Contracaecum nematodes mainly in raw fish. Contracaecum larvae infected those fishes which mentioned above in Sulaimani Province in the present study, especially L. xanthopterus with prevalence of $19.35 \%$ and it may affect the human health in this region because this fish is used by local people consumers as one of the most delicious fishes.

\section{Conclusion and recommendation}

The Contracaecum larvae infect many different fish species in Sulaimani Province and they are belonging to Contracaecum rudolphii $\mathrm{B}$. The study of larval stage (inside their cysts) resistance to salt, $\mathrm{pH}$, temperature and freezing in the laboratory is necessary in order to know the weak point of the larva and prevent contracaecosis.

\section{Acknowledgement}

We are grateful to Dr. Taeeb A. Hamasur (Sulaimani Polytechnic University) for his help during the molecular study.

\section{Conflicts of interest}

The authors declare that they have no conflict of interests. 


\section{ORCID}

\section{Y.S. Abdullah http://orcid.org/0000-0002-6583- 006X}

S.M.A.

Abdullah

shamall_m_a_abdullah@yahoo.com

\section{R. H. Hussein ridha.hussein@ univsul.edu.iq}

\section{References}

Abdullah, S. M. A., \& Rasheed, A. -R. A. -M. (2004). Parasitic fauna of some freshwater fishes from Dokan lake, north of Iraq II: Endoparasites. Ibn AlHaitham Journal for Pure and Applied Science, 17: 01-12.

Al-Alusi, M. A. (2011). Survey of some parasitic worms on three fish species from Euphrates River at Al-Haklania District, Al-Anbar Province. Ibn AlHaitham Journal for Pure and Applied Science, 24, 69-75.

<https://en.uobaghdad.edu.iq/jih/index.php/j/article/ view/875

Al-Awadi, H. M. H., \& Mhaisen, F. T. (2010). Parasitic fauna of fishes in Bahr Al-Najaf depression, mid Iraq. Bulletin of Iraq Natural History Museum, 11, 1-9. https://jnhm.uobaghdad.edu.iq/index.php/BINHM/a rticle/view/133

Ali, N. M., Salih, N. E., \& Abdul-Ameer, K. N. (1987). Parasitic fauna of some freshwater fishes from Tigris river, Baghdad, Iraq, IV: Nematoda. Journal of Biological Science Research, 18, 35-45.

Ali, N. M., Mhaisen F. T., Abul-Eis E. S., \& Kadim, L.S. (1989). Helminth parasites of the mugilid fish Liza abu (Heckel) inhabiting Babylon fish farm, Hilla, Iraq. Proceeding $5^{\text {th }}$ Scientific Conference/ SRC-Iraq Baghdad, 5, 225-233.

Al-Jadoa, N. A. (2008). Study of parasitic infection in Liza abu in drainage water in Diwanyia Province. Journal of Babylon University for Pure and Applied Science, 15, 256-263.

Al-Moussawi, A. A., Hadi, A. M., \& Macawi, Z. A. (2018). Diagnosis of Some Parasites of Asian Catfish Silurus triostegus (Heckel, 1843). Advance in Bioresearch, 9, 86-90.

Al-Nasiri, F. S., Mhaisen, F. T., \& Al-Nasiri, S. K. (2002). Parasitic infection of the common carp, Cyprinus carpio in a man-made lake at Baghdad region. Iraqi Journal of Agriculture Research, 7, 175-181.

Amlacher, E. (1970). Textbook of fish diseases, (Engl.Transl.). T.F.H. Publ., Jersey City, 302pp.

Anderson, R. C. (2000). Nematode parasites of vertebrates: Their development and transmission, 2nd ed. Wallingford: CABI Publ., CAB Int.: 650pp. https://doi.org/10.1079/9780851994215.0000

Audicana, M. T., Ansotegui, I. J., de Corres, L. F., \& Kennedy, M. W. (2002). Anisakis simplex: dangerous-dead and alive. Trends in Parasitology, 18, 20-25. https://doi.org/10.1016/s14714922(01)02152-3

Audicana, M. T., \& Kennedy, M. W. (2008). Anisakis simplex: from obscure infectious worm to inducer of immune hypersensitivity. Clinical Microbiology Reviews, 21, 360-379. https://doi.org/10.1128/CMR.00012-07

Balasem, A. N., Mhaisen, F. T, Al-Shaikh, S. M. J., AlKhateeb, G. H., Asmar, K. R., \& Adday, T. K. (1993). Survey of fish parasites from Tigris river at Al-Zaafaraniya, south of Baghdad, Iraq. Marina Mesopotamica, 8, 226-235.

Bezerra, T. N., Decraemer, W., Eisendle-Flöckner, U., Hodda, M., Holovachov, O., Leduc, D., Miljutin, D., Mokievsky, V., Peña Santiago, R., Sharma, J., Smol, N., Tchesunov, A., Venekey, V., Zeng, Z., \& Vanreusel, A. (2019). Nemys: World database of nematodes Contracaecum Railliet \& Henry, 1912. Accessed through: World Register of Marine Species at, on 2019-01-15. http://www.marinespecies.org/aphia.php?p=taxdeta ils\&id=22849.

Bush A. O., Lafferty K. D., Lotz J. M., \& Shostak A. W. (1997). Parasitology meets ecology on its own terms: Margolis et al. revisited. Journal of Parasitology, 83, 575-583. https://doi.org/10.2307/3284227

Coad, B. W. (2010). Freshwater fishes of Iraq. Pensoft Publ., Sofia: 274pp. + 16pls.

D’Amelio, S., Cavallero, S., Dronen, N. O., Barros, N. B., \& Paggi, L. (2012). Two new species of Contracaecum Railliet \& Henry, 1912 (Nematoda: Anisakidae), C. fagerholmi n. sp. and C. rudolphii $\mathrm{F}$ from the brown pelican Pelecanus occidentalis in the northern Gulf of Mexico. Systematic Parasitology, 81, 1-16. https://doi.org/10.1007/s11230-011-9323-x. 


\section{Abdullah et al. / Basrah J. Agric. Sci., 34(1): 93-110, 2020}

Eassa, A. M., Al-Jenaei A. M., Abdul-Nabi, Z. A., Abood, M. A.; Kzaal, R. S., \& Aliwy, Y. J. (2014). Comparative ecological study of pathogen structure between wild and cultured common carp Cyprinus carpio L. in Basrah. Marsh Bulletin, 9, 107-123.

Freyhof, J., \& Abdullah, Y. S. (2017). Two new species of Oxynoemacheilus from the Tigris drainage in Iraqi Kurdistan (Teleostei: Nemacheilidae), Zootaxa, 4238, 073-087. https://doi.org/10.11646/zootaxa.4238.1.5

Freyhof, J., Abdullah, Y. S., Ararat, K., Hamad, I., \& Geiger, M. F. (2016). Eidinemacheilus proudlovei, a new subterranean loach from Iraqi Kurdistan (Teleostei; Nemacheilidae), Zootaxa, 4173, 225236. https://doi.org/10.11646/zootaxa.4173.3.2

Freyhof, J., \& Geiger, M. (2017). Oxynoemacheilus zarzianus, a new loach from the Lesser Zab River drainage in Iraqi Kurdistan (Teleostei: Nemacheilidae). Zootaxa, 4273, 258-270. https://doi.org/10.11646/zootaxa.4273.2.6

Garbin, L., Mattiucci, S., Paoletti, M., GonzalezAcuna, D., \& Nascetti, G. (2011). Genetic and Morphological Evidences for the Existence of a New Species of Contracaecum (Nematoda: Anisakidae) Parasite of Phalacrocorax brasilianus (Gmelin) From Chile and Its Genetic Relationships with Congeners From Fish-Eating Birds. Journal of $\begin{array}{llll}\text { Parasitology, } & 97 & \text { (3): } & \text { 476-492. }\end{array}$ https://doi.org/10.1645/GE-2450.1.

Garbin, L. E, Mattiucci, S., Paoletti, M., Diaz, J. I., Nascetti, G., \& Navone, G. T. (2013). Molecular identification and larval morphological description of Contracaecum pelagicum (Nematoda: Anisakidae) from the anchovy Engraulis anchoita (Engraulidae) and fish-eating birds from the Argentine North Patagonian Sea: Parasitology International, 62, 309-319. https://doi.org/10.1016/j.parint.2013.03.001.

Herzog, P.H. (1969). Untersuchungen über die parasiten der süBwasserfische des Irak. Archiv für Fischereiwissenschaft, 20, 132-147.

Kamangar, B. B., Prokofiev, A. M., Ghaderi, E., \& Nalbant, T.T. (2014). Stone loaches of Choman River system, Kurdistan, Iran (Teleostei: Cypriniformes: Nemacheilidae). Zootaxa, 3755, 3361. https://doi.org/10.11646/zootaxa.3755.1.2.

Khalifa, A. K., Hassan, F. K., Atiah, H. H., \& Latif, B. M. A. (1978). Parasitic infestation of fishes in Iraq waters. Iraqi Journal of Biological Sciences, 6, 5863.

Kijewska, A., Fernandez, M., Zdzitowiecki, K., Rokicki, J., \& Wrobel, B. (2008). Analysis of 5.8S rDNA and Internal Transcribed Spacer 1 (ITS1) Sequences of Ascaridoid Nematodes: Phylogenetic Signal and Hypothesis Testing. Genes and Genomics, 30, 291-306

Køie, M., \& Fagerholm, H. (1995). The life cycle of Contracaecum osculatum (Rudolphi, 1802) sensu stricto (Nematoda, Ascaridoida, Anisakidae) in view of experimental infections: Parasitology Research, $\quad 81, \quad 481-489$. .https://doi.org/10.1007/BF00931790

Kumar S., Stecher G., Li, M., Knyaz, C., \& Tamura, K. (2018). MEGA X: Molecular evolutionary genetics analysis across computing platforms. Molecular Biology and Evolution, 35, 1547-1549. https://doi.org/10.1093/molbev/msy096

Li, A.X., D'Amelio, S., Paggi, L., He, F., Gasser, R.B., Lun, Z.R., Abollo, E., Turchetto, M., \& Zhu, X.Q. (2005). Genetic evidence for the existence of sibling species within Contracaecum rudolphii (Hartwich, 1964) and the validity of Contracaecum septentrionale (Kreis, 1955) (Nematoda: Anisakidae). Parasitology Research, 96, 361-366. . https://doi.org/10.1007/s00436-005-1366-y

Malviya, S., Jaiswal, N., \& Malhotra, S. K. (2018). Molecular diagnostic procedures using RT-PCR to alleviate taxonomic impediments of parasite species segregation. MOJ Proteomics and Bioinformatics, 7 ,

53-56..

https://doi.org/10.15406/mojpb.2018.07.00213

Mattiucci, S., Cipriani, P., Paoletti, M., Nardi, V., Santoro, M., Bellisario, B., \& Nascetti, G. (2015). Temporal stability of parasite distribution and genetic variability values of Contracaecum osculatum sp. D and C. osculatum sp. E (Nematoda: Anisakidae) from fish of the Ross Sea (Antarctica). International Journal for Parasitology: Parasites and Wildlife, 4, 356-367. https://doi.org/10.1016/j.ijppaw.2015.10.004.

Mattiucci S., Paoletti, M., Olivero-Verbel, J., Baldiris, R., Arroyo-Salgado, B., Garbin, L., Navone, G. \& Nascetti, G. (2008). Contracaecum bioccai n. sp. from the brown pelican Pelecanus occidentalis (L.) in Colombia (Nematoda: Anisakidae): morphology, molecular evidence and its genetic relationship with congeners from fish- 


\section{Abdullah et al. / Basrah J. Agric. Sci., 34(1): 93-110, 2020}

eating birds. Systematic Parasitology, 69, 101121. https://doi.org/10.1007/s11230-007-9116-4.

Mhaisen, F. T. (2020). Index-catalogue of parasites and disease agents of fishes of Iraq. (Unpublished: mhaisenft@yahoo.co.uk).

Mhaisen, F. T., \& Abdullah, S. M. A. (2017). Parasites of fishes of Kurdistan Region, Iraq: Checklists. Biological and Applied Environmental Research, 1, 131-218.

file://C:/Users/Excellence/Downloads/308185.pdf

Mhaisen, F. T., Al-Salim, N. K., \& Khamees, N. R. (1986). The parasitic fauna of two cyprinid and a mugilid fish from Mihaijeran Greek, Basrah. Journal of Biological Science Research, 17, 63-73.

Mhaisen, F. T., Khamees, N. R., \& Al-Daraji, S. A. M. (1993). Parasites and disease agents of marine and freshwater fishes of Basrah Province, Iraq. Marina Mesopotamica, 8, 45-61.

Mhaisen, F. T., Al-Saadi, A. A., \& Al-Shamma'a, A. A. (1999). Some observations on fish parasites of Habbaniya lake. Ibn Al-Haitham Journal for Pure and Applied Science, 12, 62-67.

Mohammad, M. K. (2016). The parasitic fauna of the exotic fish Tilapia zillii in the middle and south of Iraq. International Journal of Current Microbiology and Applied Sciences, 5, 93-96.

Molnár, K., Székely, C., Baska, F., Müller, T., Zuo, S., Kania, P. W., Nowak, B., \& Buchmann, K. (2019). Differential survival of 3rd stage larvae of Contracaecum rudolphii type B infecting common bream (Abramis brama) and common carp (Cyprinus carpio). Parasitology Research, 118, 2811-2817. https://doi.org/10.1007/s00436-019$06441-4$.

Moravec, F. (2009). Experimental studies on the development of Contracaecum rudolphii (Nematoda: Anisakidae) in copepod and fish paratenic hosts. Folia Parasitologica, 56, 185-193. https://doi.org/10.14411/fp.2009.023.

Moravec, F., \& Yooyen, T. (2011). Two new species of Rhabdochona (Nematoda: Rhabdochonidae) from freshwater fishes in Thailand. Folia Parasitologica, 58, 224-232. https://doi.org/10.14411/fp.2011.021.

Nadler, S. A., \& Hudspeth, D. S. (2000). Phylogeny of the Ascaridoidea (Nematoda: Ascaridida) based on three genes and morphology: hypotheses of structural and sequence evolution. Journal of
Parasitology, 86,

https://doi.org/10.1645/0022-

3395(2000)086[0380:POTANA]2.0.CO;2.

Pekmezci, G. Z., \& Yardimci, B. (2019). On the occurrence and molecular identification of Contracaecum larvae (Nematoda: Anisakidae) in Mugil cephalus from Turkish waters. Parasitology Research, 118, 1393-1402. https://doi.org/10.1007/s00436-019-06278-x.

Shamsi, S. (2019). Parasite loss or parasite gain? Story of Contracaecum nematodes in antipodean waters. Parasite Epidemiology and Control, 3, 1-7. https://doi.org/10.1016/j.parepi.2019.e00087.

Shamsi, S., \& Aghazadeh-Meshgi, M. (2011). Morphological and genetic characterisation of selected Contracaecum (Nematoda: Anisakidae) larvae in Iran. Iranian Journal of Fisheries Sciences, $\quad 10, \quad 356-361$. https://jifro.areeo.ac.ir/article_114143_9d3a18f929f 5b4a9efea690b09be6adf.pdf.

Shamsi, S., Gasser, R., Beveridge, I., \& Shabani, A. A. (2008). Contracaecum pyripapillatum n. sp. and a description of $C$. multipapillatum (von Drasche, 1882) from the Australian pelican, Pelecanus conspicillatus- Parasitology Research, 103, 10311039. https://doi.org/10.1007/s00436-008-1088-z.

Shamsi, S., Gasser, R. B., \& Beveridge, I. (2011). Mutation scanning coupled sequencing of nuclear ribosomal DNA spacers as a tool for the specific identification of different Contracaecum (Nematoda: Anisakidae) larval types. Molecular and Cellular Probes, 25, 13-18. https://doi.org/10.1016/j.mcp.2010.09.003.

Shamsi, S., Norman, R., Gasser, R., \& Beveridge, I. (2009a). Redescription and genetic characterization of selected Contracaecum spp. (Nematoda: Anisakidae) from various hosts in Australia. Parasitology Research, 104, 1507-1525. https://doi.org/ 10.1007/s00436-009-1357-5.

Shamsi, S., Norman, R., Gasser, R., \& Beveridge, I. (2009b). Genetic and morphological evidences for the existence of sibling species within Contracaecum rudolphii (Hartwich, 1964) (Nematoda: Anisakidae) in Australia. Parasitology Research, 105, 529-538. https://doi.org/10.1007/s00436-009-1424-y.

Shamsi, S., Turner A., \& Wassens, S. (2017). Description and genetic characterization of a new 


\section{Abdullah et al. / Basrah J. Agric. Sci., 34(1): 93-110, 2020}

Contracaecum larval type (Nematoda: Anisakidae) from Australia. Journal of Helminthology, 92, 216222. https://doi.org/10.1017/S0022149X17000360.

Shamsuddin, M., Nader, I. A., \& Al-Azzawi, M. J. (1971). Parasites of common fishes from Iraq with special reference to larval form of Contracaecum (Nematoda: Heterocheilidae). Bulletin of the Biological Research Center, 5, 66-78.

Szostakowska, B., \& Fagerholm, H-P. (2007). Molecular identification of two strain of third-stage larvae of Contracaecum rudolphii sensu lato (Nematoda: Anisakidae) from fish in Poland. Journal of Parasitology, 93, 961-964. https://doi.org/10.1645/GE-1100R.1.

Tamura, K., \& Nei, M. (1993). Estimation of the number of nucleotide substitutions in the control region of mitochondrial DNA in humans and chimpanzees. Molecular Biology and Evolution, 10, $512-526$

https://doi.org/10.1093/oxfordjournals.molbev.a040 023.

Umehara, A., Kawakami, Y., Araki, J., \& Uchida, A. (2008). Multiplex PCR for the identification of Anisakis simplex sensu stricto, Anisakis pegreffii and the other anisakid nematodes. Parasitology Internatinal, 57, 49-53. https://doi.org/ 10.1016/j.parint.2007.08.003.

Yagi, K., Nagasawa, K., Ishikura, H., Nakagawa, A., Sato, N., Kikuchi, K., \& Ishikura, H. (1996). Female worm Hysterothylacium aduncum excreted from human: A case report. Japanese Journal of Parasitology,

45 ,

12-23. https://eurekamag.com/research/008/681/00868186 1.php

Younis, A. E., Saad, A. I., \& Rabei, J. M. (2017). The occurrence of Contracaecum sp. larvae (Nematoda: Anisakidae) in four teleostean species from Lake Nasser, Egypt: Morphological and molecular studies. The Journal of Basic and Applied Zoology, 78, 01-13. https://doi.org/10.1186/s41936-0170012-4.

Zhang, Y., Chen, W., Lin, R., Huang, M., Song, H., \& Zhu, X. (2009). Molecular identification of Contracaecum rudolphii (Nematoda: Anisakidae) from Phalacrocorax carbosinensis in Guangzhou zoo. Journal of Tropical Medicine (Guangzhou), 9, 01-03.

https://www.semanticscholar.org/paper/Molecularidentification-of-Contracaecum-rudolphii-YuanWu/307036f4286d8d55a2bb10cb3735402e3e7bffaf

Zhu, X., D'Amelio, S., Hu, M., Paggi, L., \& Gasser, R. B. (2001). Electrophoretic detection of population variation within Contracaecum ogmorhini (Nematoda: Ascaridoidea: Anisakidae). Electrophoresis, $\quad 22, \quad 1930-1934$. https://doi.org/10.1002/1522-

2683(200106)22:10<1930::AID-

ELPS1930>3.0.CO;2-Z

Zuo, S., Kania, P. W., Mehrdana, F., Marana, M. H., \& Buchmann, K. (2018). Contracaecum osculatum and other anisakid nematodes in grey seals and cod in the Baltic Sea: molecular and ecological links. Journal of Helminthology, 92, 81-89. https://doi.org/10.1017/S0022149X17000025 
Abdullah et al. / Basrah J. Agric. Sci., 34(1): 93-110, 2020

\section{دراسة مظهرية وجزيئية ليرقة الديان الخيطية Contracaecum في بصض أنواع الأسماك في محافظة}

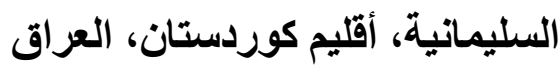

يونس صابر عبدالله, شمال محمدامين عبداللهُ, رضا حسن حسين3

1قسم التحليلات المرضية، كلية التقنية الصحية، جامعة بوليتكنيك السليمانية، العر اق

2قسم المو ارد السمكية و الاحياء المائية، كلية علوم الهندة الزراعية، جامعة صلاح الدين، اربيل، العراق

3قنم الاحياء، كلية العلوم، جامعة السليمانية، العراق

المستخلص: كونتراسيكام (Contracaecum) هو جنس من الديدان الخيطية ينتمي إلى عائلة Anisakidae، وهي طفيليات للعديد من الأسماك التي تعمل كمضيف وسطي، الطيور والثدييات الآكلة الأسماك هي مضايف هنيف نهائية. تم عزل 44 يرقة من الطور الثالث من Contracaecum من 13 سمكة مصابة تعود إلى خمسة أنواع مختلفة. جمعت الأسماك من المسطحات المائية المختلفة في محافظة السليمانية، إقليم كردستان العراق، خلال الفترة المحصورة بين شهر كانون الثاني وحتى نهاية كانون الأول 2018 خلال الدراسة الحالية، تم جمع 966 سمكة وهي ستة انواع من العائلة Nemacheilidae وخمسة انواع من عائلة الشبوطيات (Cyprinidae)، وثلاثة انواع من العائلة Leuciscidae، ونوعين من العائلة Xenocyprididae، ونوع واحد من كل مل من

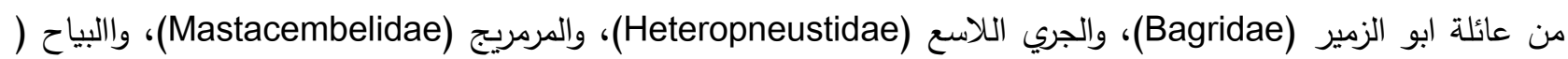

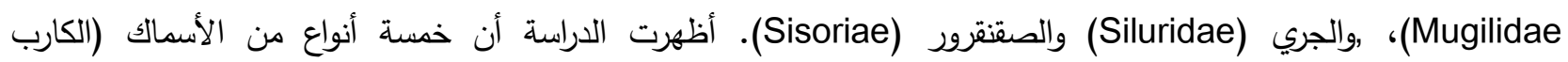

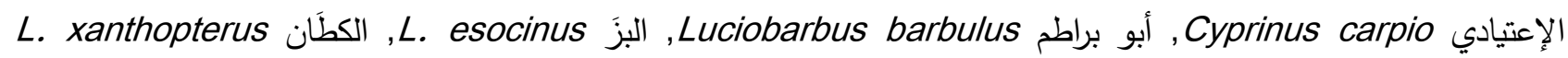
والمردريج Mastacembelus mastacembelus) أصيبت بيرقات Contracaecum بنسبة انتشار 2.05\% و 1.92٪ و 19.35٪ و 1.06٪. على التوالي. تمّت دراسة الثكل الخارجي لهذه اليرقات بواسطة المجهر الضوئي.كما أجريت

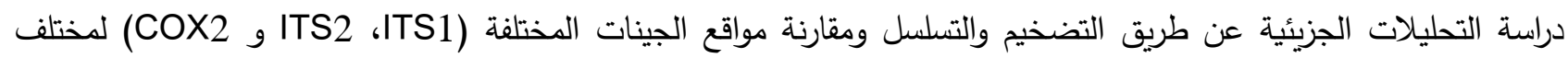
يرقات Contracaecum المعزولة. تمّ الحصول على 15 تسلسلً لهذه اليرقة التي تمّ جمعها. تمّ تضخيم ITS1، ITS2 و و Contracaecum وتسلسلها. وكثفت أن عينات يرقات Polymer chain reaction عن طريق تفاعل سلسلة البلمرة COX2 التي تمّ جمعها من خمسة أنواع من الأسماك تعود لنوع واحد وهو Contracaecum rudolphii B إستتادًا إلى نسبة الهوية في قاعدة بيانات بنك الجينات. وقد تمّ وصف التحليل الوراثي للنمط الوراثي. التوصيف الوراثي لهذه اليرقات في هذه الدراسة متاح في قاعدة بيانات بنك الجينات. تمّ إيداع تسلسلات ITS1، ITS2 و COX2 التي تمّ الحصول عليها في GenBank وأظهرت أرقام 